J. Lake Sci. (湖泊科学), 2015, 27(2): 297-304

http: //www. jlakes. org. E-mail : jlakes@niglas.ac.cn

(C) 2015 by Journal of Lake Sciences

\title{
江汉平原湖群藻相特征及其环境状况评价*
}

\author{
${\text { 严平川 }{ }^{1} \text {, 王 } \text { 军 }^{1} \text {, 肖贵清 }}^{2}$, 毕永红 ${ }^{3 * *}$ \\ ( 1 : 湖北省荆州市水文水资源勘测局,荆州 434000) \\ $(2$ : 湖北省水文水资源局,武汉 430071$)$ \\ (3: 中国科学院水生生物研究所, 中国科学院藻类生物学重点实验室, 武汉 430072)
}

\begin{abstract}
摘 要: 于 2011 年 4 月-2012 年 5 月丰、平、枯 3 个水期对江汉平原水面面积为 $10 \mathrm{~km}^{2}$ 以上的 22 个湖泊进行了水质和藻 类同步监测. 结果显示: 江汉平原主要湖泊中鉴定出藻类 7 门 100 属 191 种 (亚种、变种), 其中蓝藻门 17 属 29 种,绿藻门 45 属 99 种, 硅藻门 26 属 40 种, 隐藻门 2 属 5 种, 裸藻门 4 属 9 种, 甲藻门 3 属 5 种, 金藻门 3 属 4 种; 全年平均藻细胞丰 度为 $0.93 \times 10^{6} \sim 84.18 \times 10^{6}$ cells $/ \mathrm{L}$, 细胞丰度以蓝藻门最高 $(50.65 \%)$, 其次是绿藻门 $(29.56 \%)$, 再次是硅藻门 $(12.30 \%)$ 、隐藻门 (6.19\%)、裸藻门 ( $0.56 \%)$ 、甲藻门 $(0.39 \%)$ 和金藻门 $(0.35 \%)$; 丰水期生物量显著高于平水期和枯 水期, Shannon-Wiener 多样性指数年均值在 $1.44 \sim 2.10$ 之间, 丰水期的多样性指数略高于其他水期; 藻类种类组成及优 势种有明显的季节变化和空间差异. 依据藻相特征的 PCA 分析将 22 个湖泊分为 4 个类群, 不同类群具有显著不同的环 境状况, 氮磷营养负荷、水质状况和开发利用程度的不同是导致湖泊分化的内在原因; 研究结果显示, 江汉平原湖群总体 上属于轻度污染状况, 水体主要是中营养状态, 丰水期与枯水期的湖泊生态环境状况具有显著差异; 以藻相特征判断 22 个湖泊存在明显的时空异质性, 部分湖泊因过度开发利用存在严重的富营养化风险; 基于湖泊生态状况的显著时空异质 性,对江汉平原湖群的管理应“因湖而异”制订科学合理的方法.
\end{abstract}

关键词: 藻相特征;富营养化;湖泊;江汉平原

\section{Characteristics of phytoplankton community and its relationship with water environment in lakes from the Jianghan Plain}

\author{
YAN Pingchuan $^{1}$, WANG Jun ${ }^{1}$, XIAO Guiqing ${ }^{2} \&$ BI Yonghong ${ }^{3}$ \\ ( 1 : Jingzhou Survey Bureau of Hydrology Resources, Jingzhou 434000, P. R. China) \\ (2: Hubei Survey Bureau of Hydrology Resources, Wuhan 430071, P. R. China) \\ (3: Key Laboratory of Algal Biology, Institute of Hydrobiology, Chinese Academy of Sciences, Wuhan 430072, P. R. China)
}

Abstract: Phytoplankton is an important composition of aquatic ecosystem, its community structure and function is always adaptable to water environment and vary with the changes of water environment. The characteristics of phytoplankton community structure could be used as an important index in the assessment of water quality. In order to understand the change of water environment in the 22 lakes from the Jianghan Plain, phytoplankton communities and water quality were investigated from April, 2011 to May, 2012. 191 taxa belonging to 7 divisions and 100 genera were identified. Among them, 29 belonged to Cyanophyta, 99 belonged to Chlorophyta, and 40 belonged to Bacillariophyta. The annual mean cell abundance was $0.93 \times 10^{6}-84.18 \times 10^{6}$ cells $/ \mathrm{L}$, the relative abundance of different divisions indicated that Cyanophyta is the highest (occupied 50. 65\%), followed by Chlorophyta (29.56\%), Bacillariophyta(12.30\%), Cryptophyta(6.19\%), Euglenophyta(0.56\%), Pyrrophyta(0.39\%) and Chrysophyta $(0.35 \%)$. The annual mean of Shannon-Wiener index was 1.44-2.10, with highest value in the flood season. Algal species and the dominant species showed the significant difference in the spatio-temporal distribution. The 22 lakes were divided into 4 groups according to PCA analysis. Characteristics of phytoplankton community and the different conditions, such as the nutrient loading, water quality and the exploitation extent were the reasons for the further polarize in the 22 lakes. It was concluded that the signifi-

* 第一次全国水利普查项目资助. 2013-10-09 收稿;2014-06-24 收修改稿. 严平川 (1976 ), 男, 高级工程师;E-mail : 754807936@ qq. com.

** 通信作者;E-mail:biyh@ ihb. ac. cn. 
cant spatio-temporal heterogeneous was found in the lakes from the Jianghan Plain, and some lakes faced serious eutrophication due to the over-exploitation. Some lake-specific measurements should be taken for the lake management.

Keywords: Phytoplankton characteristics; eutrophication; lake; Jianghan Plain

湖 (泊) 群与人类文明起源、社会经济的发展关系密切. 探讨湖 (泊) 群地区发展的基本理论, 通过湖 (泊) 群地区演化过程分析找出规律, 提出湖 (泊) 群地区可持续发展的对策具有重要的理论和现实意义, 有 助于丰富湖 (泊) 群地区研究的内涵和可持续发展的理论范畴, 指导湖 (泊) 群地区的合理开发, 从更大范围 上促进区域的全面发展. 江汉平原分布有大小湖泊约 300 多个, 统称为江汉湖群. 这些湖泊有着提供水资 源、调蓄洪水、水产养殖、旅游观光、维系生态平衡和生物多样性等重要功能. 江汉湖群位于湖北省境内, 是 整个长江中下游淡水湖泊的重要组成部分. 在地质历史时期, 江汉湖群经历了复杂的演化过程; 在近代, 江 汉湖群演化又深深打上了人类的烙印. 江汉湖群所在地江汉平原是我国重要的粮食生产基地和经济发达地 区, 在我国空间经济布局上有重要地位; 同时该地区又是我国典型的生态环境脆弱地区, 长期以来, 对江汉 湖群的研究没有引起足够的关注和重视, 缺乏有价值的历史资料. 近年来, 陆续有学者开始关注江汉湖群的 历史变迁 ${ }^{[1-2]}$ 、面源污染负荷 ${ }^{[3]}$ 、水资源管理 ${ }^{[4]}$ 等; 尤其是近年来由于江湖阻隔、围垦造田、拦湖筑汉等不当 开发行为, 加之管理无序、开发过度、保护不力等多种因素叠加, 导致湖泊数量锐减、面积萎缩、水体污染、富 营养化等问题突出, 引起了众多专家学者对江汉平原湖泊生态现状的关注 ${ }^{[5-7]}$, 但对于水体生态环境研究依 然匮乏, 江汉湖群水域生态环境调查研究的匮乏对于认识和了解江汉湖群的水生态环境状况极为不利, 因 此有必要加强对江汉湖群的生态环境研究, 以期为湖群管理、治理和保护提供理论依据. 本研究以江汉平原 主要湖泊的水质、藻类生态为调查内容, 从湖泊藻相特征人手, 评价水体污染状况及营养状况, 旨在为未来 的湖泊开发利用、生态修复与管理决策提供参考依据.

\section{1 材料与方法}

\section{1 调查区域}

本次调查监测对象为江汉平原水面面积大于或近于 $10 \mathrm{~km}^{2}$ 的 22 个湖泊, 包括: 荆州市的洪湖、淤泥湖、上津 湖、天鹅湖、天星湖、崇湖、小南海、菱角湖、老江湖, 荆门市的南湖, 孝感市的汀汉湖、野猪湖、龙赛湖、东西汉湖, 武 汉市的后官湖、小容湖、沉湖, 以及跨省界湖泊牛浪湖和 4 个跨市界湖泊: 长湖、借粮湖、五湖和西湖 (图 1).

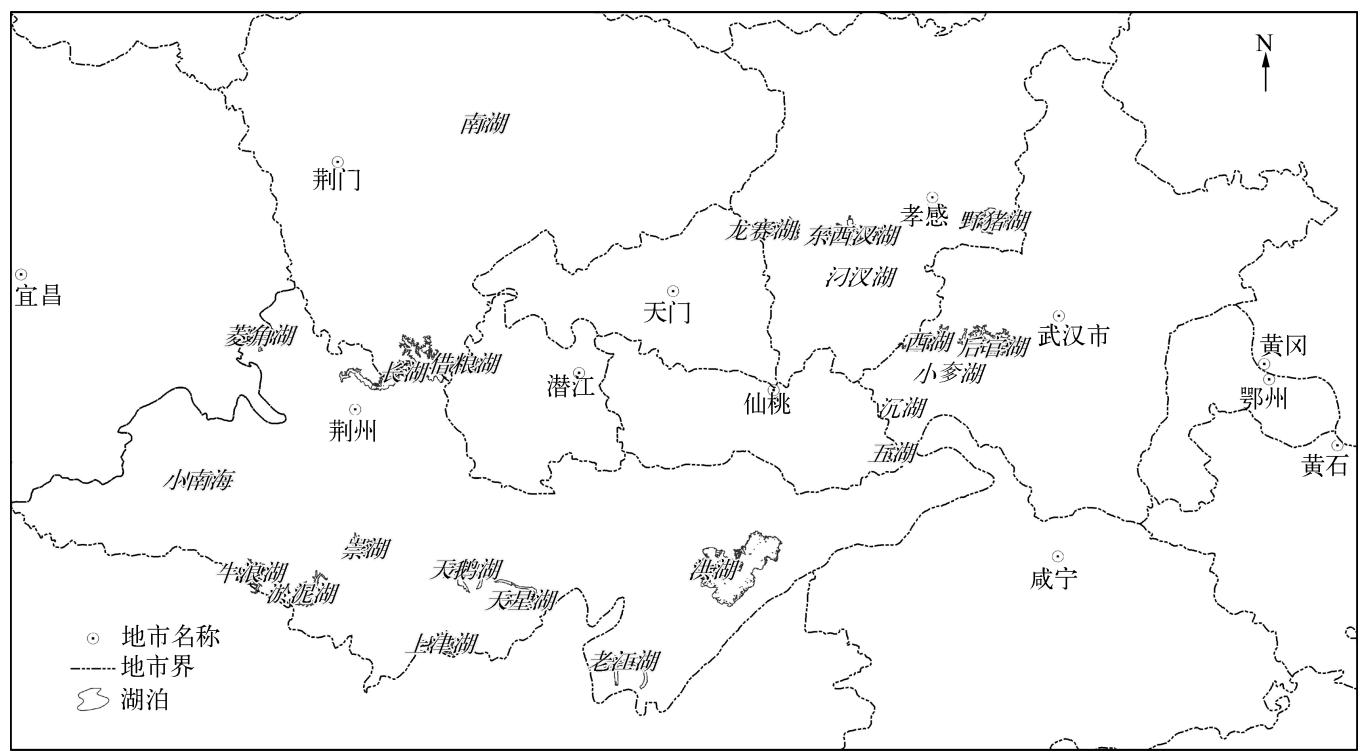

图 1 江汉平原采样湖泊示意图

Fig. 1 Sketch map of sampling lakes from the Jianghan Plain 


\section{2 采样点布设与采样时间}

采样点布设在每个湖泊的进出口水域、纳污水域、清洁水域等代表湖泊生态现状的水域, 藻类调查与水 质监测采样点一致. 当水深小于 $3 \mathrm{~m}$ 、水体混合均匀、透光可达水底层时, 藻类采样点布设在水面下 $0.5 \mathrm{~m}$; 个 别湖泊水深大于 $3 \mathrm{~m}$ 时, 取水面和 $1 / 2$ 水深处混合样.

监测时间为 2011 年 4 月- 2012 年 5 月, 分丰 (7-8 月)、平 (11-12 月)、枯( $1-3$ 月) 3 个水期进行. 采 样时间一般选择在上午 $8: 00-10: 00$,并尽量避开阴雨天气.

\section{3 监测指标}

常规水质参数选取透明度 $(\mathrm{SD})$ 、酸碱度 $(\mathrm{pH})$ 、溶解氧 $(\mathrm{DO})$ 、总氮 $(\mathrm{TN})$ 、总磷 $(\mathrm{TP})$ 、高锰酸盐指数 $\left(\mathrm{COD}_{\mathrm{Mn}}\right)$ 、叶绿素 $\mathrm{a}(\mathrm{Chl} . \mathrm{a})$ 、铵态氮 $\left(\mathrm{NH}_{4}^{+}-\mathrm{N}\right)$ 、五日生化需氧量 $\left(\mathrm{BOD}_{5}\right)$ 、铜、铅、锌、镉等进行分析, 分析方 法参照 《水和废水监测分析方法》 ${ }^{[8]}$. 参照《地表水环境质量标准》(GB3838-2002), 采用单因子法对湖泊水 质进行评价.

藻类和常规水质参数同步监测. 藻类样品的采集、处理、分类鉴定参照《水生生物监测手册》 ${ }^{[9]}$ 、《水环境 监测规范》 (SL219-1998) 和《中国淡水藻类——系统、分类及生态》 ${ }^{[10]}$ 进行.

\section{4 多样性指数和营养状况指数}

藻类物种多样性分析采用 Shannon-Wiener 多样性指数 $(H)$, 并进行污染程度评价.

$$
H=-\sum_{i=1}^{S} p_{i} \cdot \ln p_{i}
$$

式中, $S$ 为藻类的种数, $p_{i}$ 为第 $i$ 种藻占所有藻数量的比例. Shannon-Wiener 多样性指数可以反映水体的水质 状况, 当物种多样性指数大于 3 时, 水体为轻污染或无污染; 指数为 $1 \sim 3$ 时为中度污染; 指数为 $0 \sim 1$ 时为重 度污染 ${ }^{[11]}$.

营养状态指数 $(T L I)$ 主要用来研究水库 (湖泊) 的营养状态 ${ }^{[12]}$. 本文使用上述测定的水质参数, 参照 《地 表水资源质量评价技术规程》(SL395-2007) 中关于湖泊富营养化评价标准对湖泊富营养化程度进行计算 并评价.

\section{5 数据分析}

用 Excel 2007 对测定的数据进行统计分析, ANOVA 分析用于检验不同水体间的藻相特征差异与水环 境差别. 藻相特征 “物种数、生物量、细胞丰度和生物多样性指数” 的 PCA 分析使用 Canoco for Windows 4. 5 软件进行.

\section{2 结果}

\section{1 湖群藻相特征}

2.1 .1 藻类组成、优势种及其季节差异 对江汉平原 22 个主要湖泊进行藻类调查, 共鉴定出浮游藻类 7 门 100 属 191 种 (亚种、变种), 其中蓝藻门 17 属 29 种, 绿藻门 45 属 99 种, 硅藻门 26 属 40 种, 隐藻门 2 属 5 种, 裸藻门 4 属 9 种, 甲藻门 3 属 5 种, 金藻门 3 属 4 种. 藻类相对细胞丰度以蓝藻门最高 ( $50.65 \%$ ), 其次是 绿藻门 $(29.56 \%)$, 然后依次是硅藻门 $(12.30 \%)$ 、隐藻门 $(6.19 \%)$ 、裸藻门 $(0.56 \%)$ 、甲藻门 $(0.39 \%)$ 和金 藻门 $(0.35 \%)$; 各个湖泊藻类细胞丰度分布差异较大. 除了崇湖、汀汉湖、老江湖、天鹅湖、小㐱湖外, 蓝藻门 是大部分湖泊中的主要藻类类群; 而在这些以蓝藻门为主要类群的湖泊中, 其他 6 门藻类的细胞丰度也存 在明显差异 (图 2).

22 个湖泊中的常见优势种为蓝藻门的水华鱼腥藻 (Anabaena flos-aquae) 、银灰平裂藻 (Merismopedia glauca)、铜绿微囊藻 (Microcystis aeruginosa)、湖生颤藻 (Oscillatoria limnitica)、中华尖头藻 (Raphidiopsis sinensia) 、湖生色球藻 (Chroococcus limneticum) 、小席藻 (Phormidium tenue) 和项圈藻 (Anabaenopsis sp.), 绿藻 门的十字藻 (Crucigenia apiculata)、镰形纤维藻 (Ankistrodesmus falcatus)、弓形藻 (Schroederia robusta)、蹄形藻 (Kirchneriella sp.)、二形栅藻 (Scenedesmus dimorphus)、四尾栅藻 (Scenedesmus quadricauda)、单角盘星藻 (Pediastrum simplex)、空球藻 (Eudorina elegans)、隐球藻 (Aphanocapsa sp.) 和新月藻 (Closterium sp.), 硅藻门的湖 北小环藻 (Cyclotella hubeiana) 、尖针杆藻 (Synedra acus)、简单舟形藻 (Navicula simplex) 和变异直链藻 (Melo- 
sira varians) 以及隐藻门的卵形隐藻 (Cryptomonas ovata).

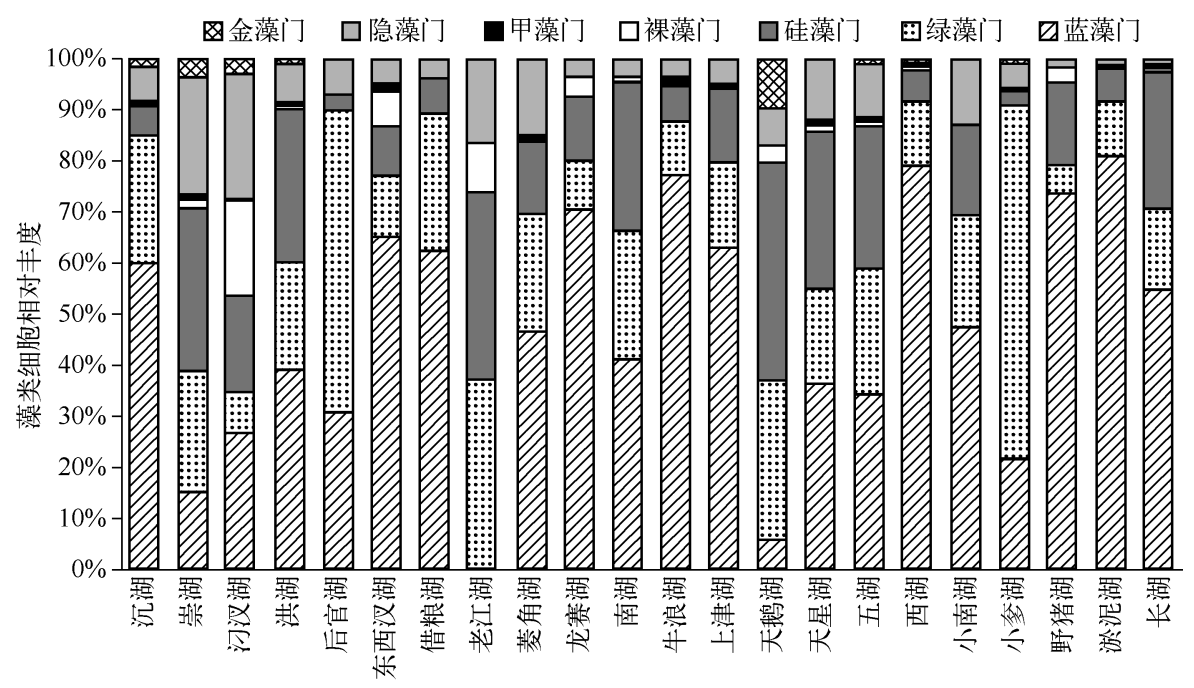

图 2 江汉平原 22 个湖泊的藻类细胞相对丰度

Fig. 2 Algal relative abundance in the 22 lakes from the Jianghan Plain

这些优势种的出现具有明显的季节特性,一般而言, 丰水期出现的主要为硅藻、绿藻和蓝藻, 平水 期则硅藻和绿藻常见,枯水期主要是硅藻、甲藻; 不同湖泊的优势种可能因水体环境差异而不同, 即便 在夏季丰水期以蓝藻为优势种时, 不同水体也存在显著不同的蓝藻优势类群; 常见优势种有微囊藻、 平裂藻、鱼腥藻、颤藻、色球藻、项圈藻等, 有时还形成以微囊藻、鱼腥藻、颤藻或束丝藻中的一种或两 种为优势种的蓝藻 “水华”. 春、秋两季所检湖泊中绿藻门种属较多, 常见优势种有纤维藻、栅藻、蹄形 藻、弓形藻、小球藻、盘星藻等. 硅藻一年四季均有出现, 以平水期检出种类较多,但是没有形成枯水期 硅藻优势种群. 常年可见的硅藻门种属有小环藻、针杆藻、直链藻以及舟形藻等. 隐、裸、甲、金藻门的 种属也有检出, 但种类不多, 部分藻种是季节性出现的, 甚至形成区域性水华, 如牛浪湖湖心区 2011 年枯水期曾出现甲藻水华. 属于清洁水域指示物种的黄藻门藻种全湖未检出, 部分湖泊在不同水期出 现以绿色裸藻 (Euglena viridis) 和甲藻 (Peridiniopsis sp.) 为优势种的独特现象; 隐藻成为菱角湖、沉湖、 小南海的常年优势种或常见种.

2.1 .2 藻类细胞丰度与生物量 22 个湖泊中平均藻类细胞丰度最高的为淤泥湖 $\left(84.18 \times 10^{6} \mathrm{cells} / \mathrm{L}\right)$, 最低 的为老江湖 $\left(0.93 \times 10^{6} \mathrm{cells} / \mathrm{L}\right)$, 其它湖泊平均藻类细胞丰度由高到低排序依次为南湖、菱角湖、小唂湖、沉 湖、后官湖、长湖、小南海、牛浪湖、上津湖、借粮湖、西湖、野猪湖、天星湖、五湖、崇湖、洪湖、龙赛湖、东西汊 湖、天鹅湖、汀汉湖 (图 3). 细胞丰度上可以将 22 个湖泊分为两个类群, 五湖、崇湖、洪湖、龙赛湖、东西汉湖、 天鹅湖和汀汉湖的细胞丰度显著低于其他湖泊 ( ANOVA, $P<0.05)$.

藻类细胞丰度存在显著的季节特性, 丰水期细胞丰度最高, 枯水期的细胞丰度最低 (图 4a), 不同水期的 藻类细胞丰度差异显著 $($ ANOVA,$P<0.05)$.

使用水体 Chl. a 含量代表水体藻类生物量, 不同湖泊藻类生物量存在显著差异 ( ANOVA, $P<0.05)$, 生 物量较高的湖泊主要是淤泥湖、小㟥湖、小南海、借粮湖、后官湖、菱角湖、牛浪湖、上津湖、南湖等水体, 以淤 泥湖、牛浪湖、南湖最高 (图 4b).

\section{2 多样性指数}

多样性指数的计算结果显示, Shannon-Wiener 指数年均值在 $1.44 \sim 2.10$ 之间 (图 4c) , 以丰水期最高; 依据多样性指数评价发现 $46.1 \%$ 的监测水面 $\left(1673 \mathrm{~km}^{2}\right)$ 为轻度污染, $52.4 \%$ 的监测水面 $\left(1903 \mathrm{~km}^{2}\right)$ 为中度 污染, 淤泥湖、牛浪湖和后官湖 3 个湖泊部分水域为重度污染. 


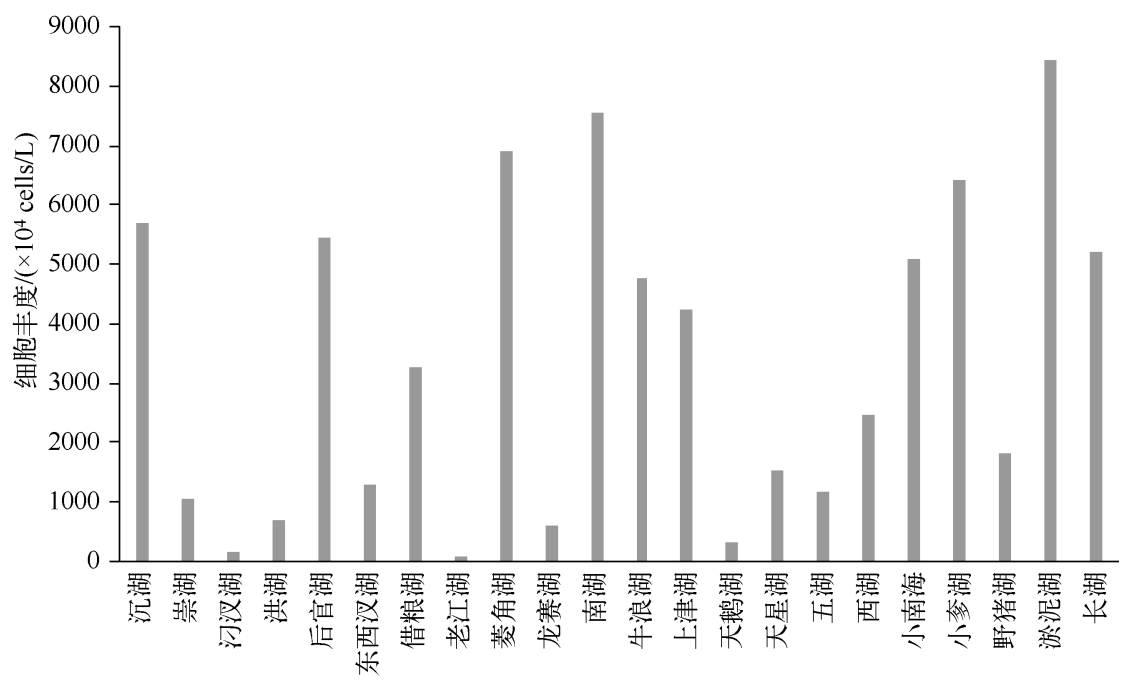

图 3 江汉平原 22 个湖泊平均藻类细胞丰度分布

Fig. 3 The mean algal cell abundance in the 22 lakes from the Jianghan Plain

\section{3 湖泊水质及营养状况评价}

22 个湖泊共监测 192 个点位, 对 $\mathrm{SD} 、 \mathrm{pH} 、 \mathrm{DO} 、 \mathrm{COD}_{\mathrm{Mn}} 、 \mathrm{Chl} . \mathrm{a} 、 \mathrm{NH}_{4}^{+}-\mathrm{N} 、 \mathrm{BOD}_{5}$ 等采用单因子法评价, 结果见 图 5. 总体上江汉湖群的水质主要类别为 III 类和 IV 类, 其中水质 I 类样点 1 处, 占 $0.52 \%$; II 类 7 处, 占 $3.6 \%$; III 类 62 处,占 $32.3 \% ; \mathrm{IV}$ 类 50 处,占 $26.0 \% ; \mathrm{V}$ 类 23 处, 占 $12.0 \%$; 劣 V类 49 处, 占 $25.5 \% . \mathrm{V}$ 类及 劣 $\mathrm{V}$ 类水质监测样点占 $37.5 \%$. 按监测水面面积统计, $\mathrm{V}$ 类及劣 $\mathrm{V}$ 类水质的监测水面面积占 $30.1 \%$.

不同水期 22 个湖泊的水质情况如图 6. 从湖泊个数所占的水质类别来看, 主要水质类别为 III 类和 IV 类, 但 $\mathrm{V}$ 类及劣 $\mathrm{V}$ 类水质的湖泊占据较大的比例,超标因子主要是 $\mathrm{TN} 、 \mathrm{COD}_{\mathrm{Mn}}$ 和 $\mathrm{NH}_{4}^{+}-\mathrm{N}$.

依据监测指标计算全部监测样点的营养状况综合指数,192 个监测点位中有 97 个为中营养, 占 $50.5 \%$; 91 个点位为轻度富营养, 占 $47.4 \%$; 有 4 个点位为中度富营养, 占 $2.1 \%$. 按照不同湖泊计算 $T L I$ 指数, 江汉 湖群的主要水体类型为中营养, 富营养水体所占比例较小; 从季节上来看, 丰水期的营养负荷最高, 其次为 枯水期,最低的是平水期; 沉湖、牛浪湖、上津湖、南湖和五湖的营养负荷全年较高, 均为轻度富营养状态 ( 图 7).

\section{3 分析与讨论}

对江汉湖群 22 个湖泊进行 PCA 分析, 结果显示 22 个湖泊大体上可以归为 4 类 (图 8 ), 野猪湖 (图中序 号为 20$)$ 独自游离在其他 21 个湖泊之外,并没有被归于任何一个类群,从藻相特征上来看,该湖藻类物种 数、生物量、细胞丰度和多样性指数均不高, 与其他湖泊的藻相特征明显不同,可能与该水体年度水交换量 较大有关. 其他 21 个湖泊被分为 4 个类群,每个类群均有各自明显的藻相特征: 类群 I 生物多样性指数和生 物量为 4 个类群所属的 21 个湖泊中最低的, 藻类细胞丰度方面蓝、绿、硅藻所占比例相近, 仅在丰水期蓝藻 略偏高,无明显优势种群; 除了丰水期,其他季节的细胞丰度显著偏低; 类群 II 的物种多样性高于类群 I , 但 生物量、细胞丰度均低于类群 I, 物种数方面, 蓝藻并未占据绝对优势, 而是与绿藻硅藻共同组成群落的主要 物种; 类群 III 生物多样性指数最高, 生物量仅仅低于类群 IV 而高于类群 I 和 II, 物种数方面蓝藻、绿藻、硅藻 为主要物种, 但以硅藻和绿藻为主体; 类群 IV 为本研究中最大的群体, 有 8 个湖泊聚集到该类群中, 其特征 主要是生物量和细胞丰度在全部湖泊中最高, 多样性指数居第二位,物种数方面蓝藻、绿藻、硅藻为主要物 种, 硅藻和蓝藻交替成为主要优势种. 

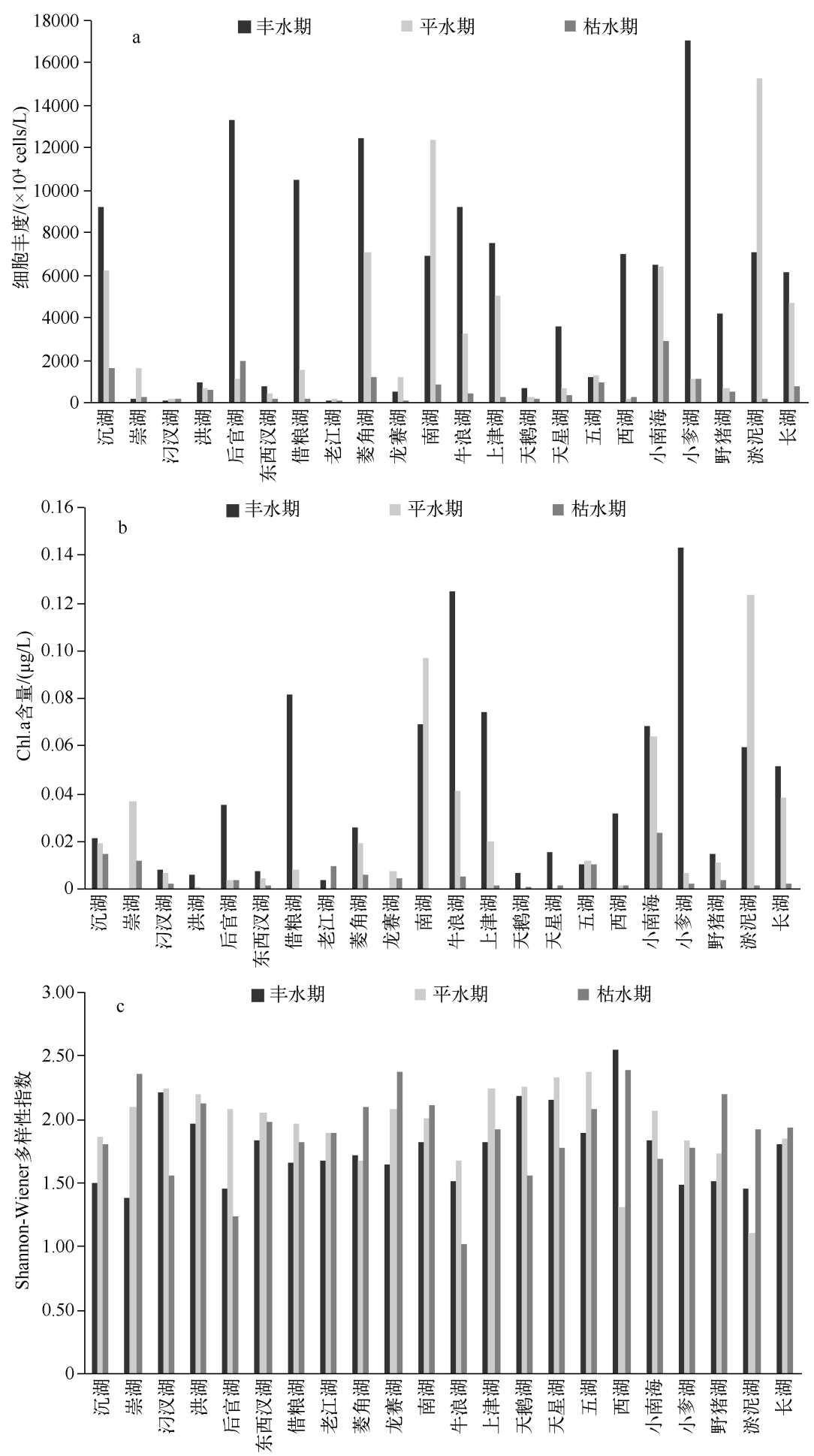

图 4 江汉平原 22 个湖泊不同水期的藻类细胞丰度 (a)、 生物量 $(\mathrm{b})$ 和 Shannon-Wiener 指数 (c)

Fig. 4 The algal cell abundance(a), biomass(b) and Shannon-Wiener indexes(c) in different water seasons in the 22 lakes from the Jianghan Plain 
口I类 $\otimes$ II类 $\square$ III类 国IV类 $\square \mathrm{V}$ 类 $\square$ 劣 V类

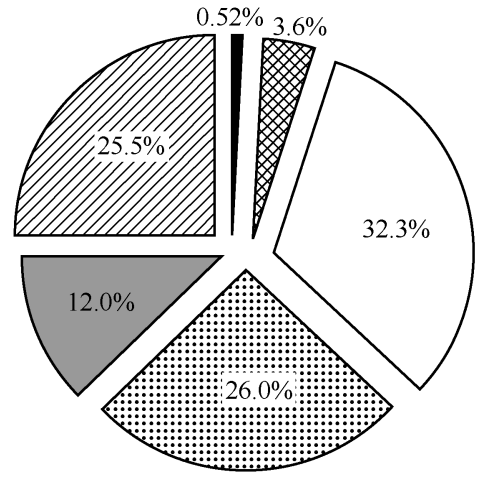

图 5 江汉平原 22 个湖泊各类水质所占比例

Fig. 5 Percentage of different water qualities of the 22 lakes from the Jianghan Plain

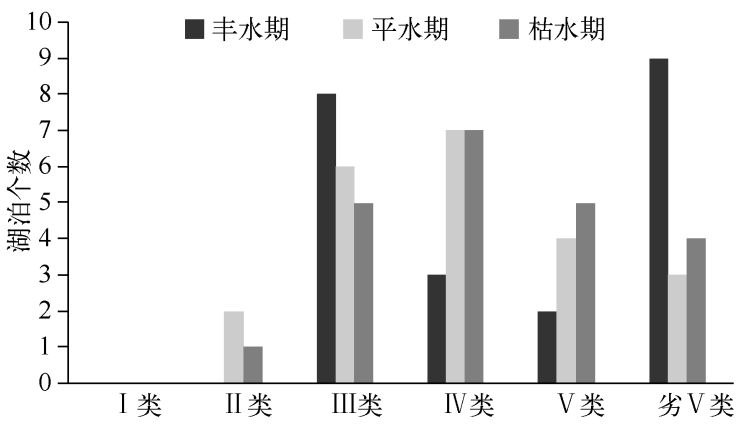

图 622 个湖泊不同水期的水质类别汇总情况

Fig. 6 Water quality in different water seasons in the 22 lakes from the Jianghan Plain

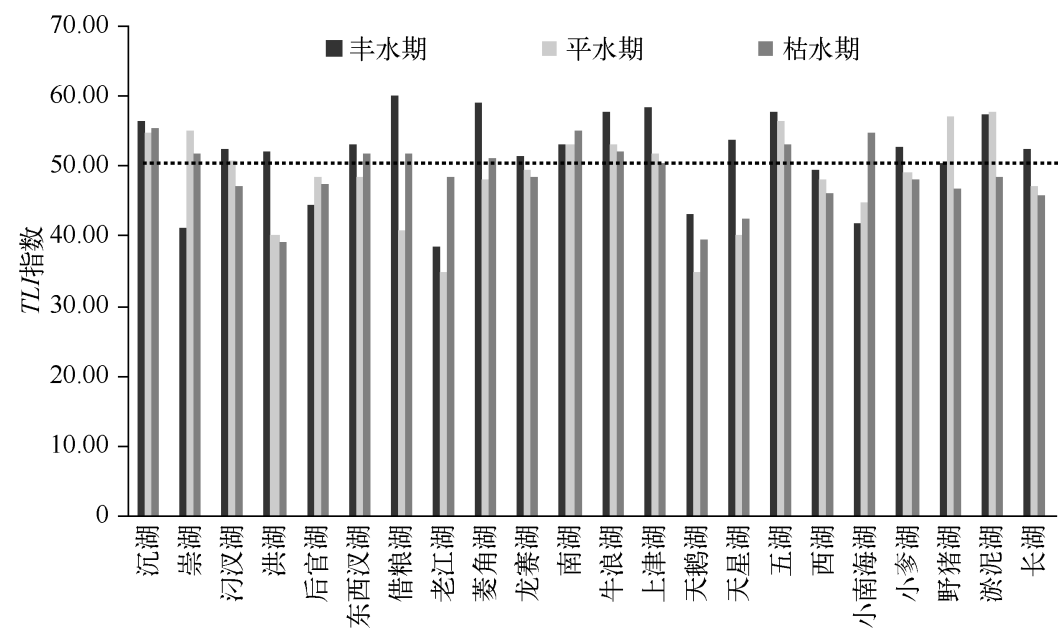

图 7 江汉平原 22 个湖泊营养状况评价 (虚线为富营养的阈值)

Fig. 7 Nutrient status of the 22 lakes from the Jianghan Plain( The dotted line stands for the threshold of eutrophication)

依据藻相特征的差异将江汉平原 22 个湖泊明显归并到不同的类群中, 这些类群具有显著的特点. 藻类 作为对环境状况敏感的生物, 它的基本特征一定程度上是水体环境质量的外在表现. 这些湖泊的水质监测 结果与 PCA 分析结果基本一致. 类群 I 与野猪湖一起, 这 5 个湖泊成为 4 个类群中水体环境状况良好的湖 泊, 受人工养殖影响较小, 污染状况较轻, 水质主要为 III IV 类, TN TP 含量相对其他水体偏低, 营养状况以 中营养为主, 轻度富营养水体所占比例极小; 类群 IV 的 8 个湖泊为全部调查湖泊中污染最严重的水域, 水质 类别主要为 $\mathrm{V}$ 类和劣 $\mathrm{V}$ 类, $\mathrm{TN}$ 含量最高达到 $3.05 \mathrm{mg} / \mathrm{L} 、 \mathrm{TP}$ 含量最高达到 $0.50 \mathrm{mg} / \mathrm{L}$, 轻度富营养是该类群 的主要营养状况. 类群 II 和 III 介于它们之间. 调查发现, 江汉湖群上游湖泊均不同程度被人类开发利用, 人 类活动对湖泊的干扰、河网水系变化、垸田开发与围湖垦殖、水利工程、长江中上游生态环境建设等都直接 作用于江汉湖群 ${ }^{[2]}$, 造成其出现明显分化, 不同干扰形式和干扰强度是湖群分化的主要驱动力, 类群 IV 所属 的 8 个湖泊是主要水产养殖区, 养殖生产活动对水体的负面影响由此可见一斑; 对这些湖泊的过度开发利 用使得藻类群落加速演变为蓝藻占绝对优势的群落类型, 改变了水体的初级生产结构和水质状况, 破坏了 水体的正常生态服务功能 ${ }^{[13]}$, 降低了湖泊所具有的经济价值 ${ }^{[14]}$. 


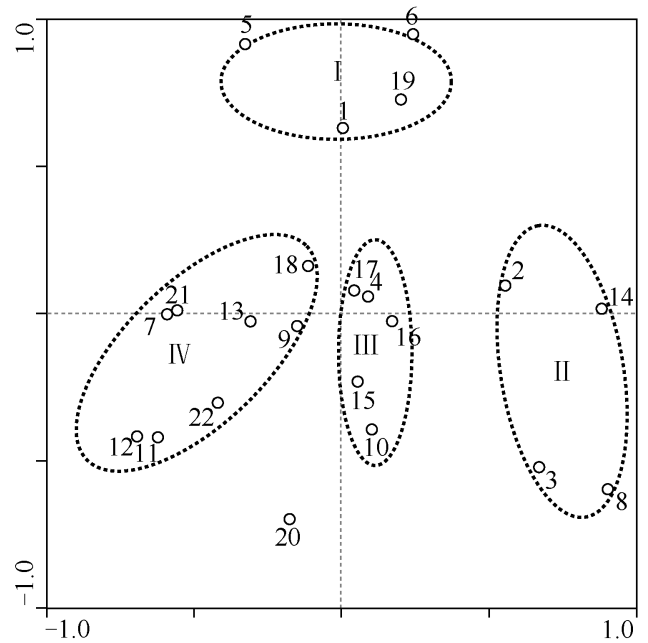

图 8 基于藻相特征的江汉湖群 PCA 分析结果 （湖泊编号 1 22 分别代表沉湖、崇湖、汀汉 湖、洪湖、后官湖、东西汉湖、借粮湖、老江湖、 菱角湖、龙赛湖、南湖、牛浪湖、上津湖、天鹅 湖、天星湖、五湖、西湖、小南海湖、小夿湖、野 猪湖、淤泥湖、长湖)

Fig. 8 The PCA analysis results based on the algal characteristics in the lakes from the Jianghan Plain
调查结果显示,江汉湖群总体生态环境状况不 容乐观, 需要引起足够重视, 加强对江汉湖群的管 理、治理力度势在必行. 由于不同湖泊具有不同特 征,需要 “因湖因地制宜” 采用不同的管理措施和治 理对策,切忌 “一刀切” 的简单粗放管理治理模式; 类群 I 所属的几个湖泊中, 水生植物和蔬菜 (苂实、 莲藕、艾白) 较多,水生植物的大量存在对于水体环 境状况有良好的净化保护作用, 为鱼类等水生生物 具有提供食物来源和营造栖息地 ${ }^{[15]}$; 对这类水体生 态环境质量尚好的水体需要加强保护管理,在保护 的基础上,以不损害水域生态环境为前提适度开发 利用生物资源, 确保湖泊的可持续发展和利用; 对 于类群 $\mathrm{IV}$ 的湖泊, 因过度利用导致水质恶化,生态 问题严重,需要严格控制开发利用力度,削减养殖 规模, 控制污染负荷 ${ }^{[16]}$; 同时, 对于特定水体需要给 予必要的治理,协助恢复水域的生态自净功能, 确 保水体环境的好转.

致谢: 衰心感谢湖北省水环境监测中心所属分中心 姚家芬、伊郎、章玉琴、蔡云等同志协助进行藻类分 类鉴定工作.

\section{4 参考文献}

[ 1 ] 何报寅. 江汉平原湖泊的成因类型及其特征. 华中师范大学学报:自然科学版,2002,6(2):241-244.

[2] 邓宏兵. 江汉湖群演化与湖区可持续发展研究 [学位论文].上海:华东师范大学,2004.

[ 3 ] 刘静静. 江汉平原湖泊面源污染效应及调控机制研究 [学位论文].荆州:长江大学,2012.

[ 4 ] 王学雷, 吕宪国, 任宪友. 江汉平原湿地水系统综合评价与水资源管理探讨. 地理科学, 2006,6(3):311-315.

[ 5 ] 彭映辉,简永兴,倪乐意等. 长湖水生植物多样性及其变化.云南植物研究,2003,25(2):173-180.

[ 6 ] 郝卫民,王士达,王德铭. 洪湖底栖动物群落结构及其对水质的初步评价. 水生生物学报, 1995, 19(2):124-133.

[ 7 ] 张 征,何 力,倪朝辉等. 湖北省钟祥市南湖水生态环境评价. 华中农业大学学报,2005,24(4):394-396.

[ 8 ] 国家环境保护总局《水和废水监测分析方法》编委会. 水和废水监测分析方法:第四版. 北京: 中国环境科学出版 社,2002.

[ 9 ] 国家环保局《水生生物监测手册》编委会. 水生生物监测手册. 南京:东南大学出版社,1993.

[10］胡鸿钧,魏印心. 中国淡水藻类——系统、分类及生态. 北京:科学出版社,2006.

[11］沈暳芬. 微型生物监测新技术. 北京:中国建筑工业出版社,1990.

[12] 王朝晖,韩博平, 胡 韧等. 广东省典型水库浮游植物群落特征与富营养化研究. 生态学杂志, 2005, 24 (4): $402-405$.

[13] Egan KJ, Herriges JA, Kling CL et al. Valuing water quality as a function of water quality measures. American Journal of Agricultural Economics, 2009, 91(1) : 106-123.

[14] Wilson MA, Carpenter SR. Economic valuation of freshwater ecosystem services in the United States: 1971 -1997. Ecological Applications, 1999, 9(3): 772-783.

[15] Pothoven SA, Vondracek B. Effects of vegetation removal on bluegill and largemouth bass in two Minnesota lakes. North American Journal of Fisheries Management, 1999, 19: 748-757.

[16] Cao L, Wang W, Yang Y et al. Environmental impact of aquaculture and countermeasures to aquaculture pollution in China. Environmental Science and Pollution Research, 2007, 14(7) : 452-462. 